\title{
Effects of temperature, salinity, and prey organisms on the growth of three Pfiesteria-like heterotrophic dinoflagellates
}

\author{
Seung Ho Baek ${ }^{1,2}$, Kai You ${ }^{1,3}$, Toshiya Katano ${ }^{1,4, *} \&$ Kyoungsoon Shin ${ }^{2}$ \\ ${ }^{1}$ Department of Life Science, Hanyang University, 17 Haengdang, Seongdong-gu, Seoul 133-791, Korea. \\ ${ }^{2}$ South Sea Institute, KORDI, Geoje 656-830, Korea. \\ ${ }^{3}$ Department of Fisheries Science, Ocean University of China, 5 Yushan Road, Qingdao 266003, China \\ ${ }^{4}$ Ariake Sea Research Project, Saga University, Honjo-machi 1, Saga 840-8502, Japan
}

Received 19 June 2009; Accepted 19 November 2009

\begin{abstract}
To clarify favorable environmental conditions for the population development of Pfiesteria-like dinoflagellates (PLDs), laboratory experiments were carried out using isolated strains of Cryptoperidiniopsis brodyi, Luciella masanensis, and Pfiesteria shumwayae. We examined the availability of 12 strains of phytoplankters which frequently cause red tides in coastal waters as food for these PLD species. In addition, the effect of temperature and salinity on the growth of these PLD species was also investigated. Three PLD species were able to feed on the cryptophyte Rhodomonas sp., the raphidophyte Heterosigma akashiwo and the dinoflagellate Akashiwo sanguinea, but not on thecate dinoflagellates. Among the three species tested, C. brodyi utilized the raphidophytes, Chattonella ovata, C. marina, and $C$. antiqua; however, two other species, L. masanensis and P. shumwayae, could not utilize these raphidophytes as food. The growth rates of PLD species generally increased with an increase in temperature in the range of 15 to $30^{\circ} \mathrm{C}$. Below $10^{\circ} \mathrm{C}$, their growth was negative. While the growth response of the three species as a function of the temperature was similar, that as a function of the salinity was different. The salinity ranges required for positive growth were 5-15, 5-25, and 5-30, respectively, for L. masanensis, P. shumwayae, and C. brodyi. The bloom of PLDs likely depends on high abundances of available phytoplankters in brackish waters when water temperature is $>15^{\circ} \mathrm{C}$.
\end{abstract}

Key words: Pfiesteria-like dinoflagellate, prey organisms, salinity, temperature

\section{Introduction}

Pfiesteria piscicida Steidinger et Burkholder and Pfiesteria-like dinoflagellates (PLDs), which are thinly armored forms

with motile dinospore stages characterized by their distinct plate formulae (Steidinger et al. 2001), cause harmful algal blooms (HAB) in coastal waters (Burkholder \& Glasgow 1997, Rublee et al. 2005, Jeong et al. 2006). Since these species are similar in morphology (Burkholder \& Glasgow 1997, Gordon et al. 2002), the identification of these dinoflagellates is based on a small subunit rRNA gene sequence and distinct plate formulae obtained by scanning electron microscopy (SEM) (Litaker et al. 1999, Taylor 1999, Steidinger et al. 2001). Until the present, Pfiesteria shumwayae Glasgow et Burkholder, Cryptoperidiniopsis brodyi Steidinger, Landsberg, Mason, Vogelbein, Tester et Litaker, Luciella masanensis Mason, Jeong, Litaker, Reece et Steidinger, L. atlantis Mason, Litaker, Reece et Steidinger, and "Stoeckeria algicida," whose description is not validly published due to lack of a latin diagnosis, have been described as PLDs (Parrow \& Burkholder 2003, Jeong et al.

*Corresponding author: Toshiya Katano; E-mail, f9130@cc.saga-u.ac.jp 2005a, Seaborn et al. 2006, Steidinger et al. 2006, Mason et al. 2007).

During the past two decades, these dinoflagellate blooms have been reported in the estuaries of the U.S.A., Australia, and Korea and have sometimes caused great economic damage to fisheries (Burkholder et al. 1992, Glasgow et al. 2001, Jeong et al. 2005a, Park et al. 2007). Since the causative species of the first red tide of PLDs was P. piscicida and the bloom caused significant damage to human health, most ecological and physiological studies have focused on the species. According to Jeong et al. (2006), P. piscicida grazes on cryptophyte species and Heterosigma akashiwo (Hada) Hada; however, the growth and ingestion rates vary widely for a given prey density. Thus, the prey densities and species in the water column likely play an important role in the bloom occurrence of PLD species. In addition, Eriksen et al. (2002) demonstrated that Cryptoperidiniopsis sp. grow better under light conditions than in dark conditions, while light had no effect on the growth of P. pis- 
cicida. They also showed that Cryptoperidiniopsis sp. retained kleptochloroplasts when they fed on cryptophyceae, Storeatula major Butcher ex Hill (Eriksen et al. 2002). Trophic modes possibly differ between PLDs.

In the present study, in order to expand the current understanding of the eco-physiology of PLDs, the response of the growth rate of C. brodyi, P. shumwayae, and L. masanensis to temperature, salinity, light conditions and prey species was determined under controlled laboratory conditions.

\section{Materials and Methods}

The clones of Cryptoperidiniopsis brodyi CCMP1828, Pfiesteria shumwayae CCMP2807, and Luciella masanensis CCMP1835 used in this study were obtained from the Provasoli-Guillard National Center for the Culture of Marine Phytoplankton (CCMP). The algal food source for the PLD species was the cryptophyte Rhodomonas sp. CCMP768, which was also received from CCMP. The prey was grown in $500 \mathrm{~mL}$ glass bottles containing an F/2-Si medium at $20^{\circ} \mathrm{C}$ under $80 \mu \mathrm{mol} \mathrm{m} \mathrm{m}^{-2} \mathrm{~s}^{-1}$ provided with a $12 \mathrm{~h}$ light : $12 \mathrm{~h}$ dark cycle (12L : 12D) using cool white fluorescent lamps. PLD species in the exponential growth phase were used for feeding experiments.

The prey test was designed to investigate whether the dinoflagellates $C$. brodyi, P. shumwayae, and L. masanensis were able to feed on each target prey species, such as Prorocentrum micans Ehrenberg, $P$. minimum (Pavillard) Schiller, $P$. triestinum Schiller, $P$. donghaiense Lu, Alexandrium tamarense (Lebour) Balech, Heterocapsa triquetra (Ehrenberg) Stein, Heterosigma akashiwo, Akashiwo sanguinea (Hirasaka) Hansen et Moestrup, Chattonella ovata Hara et Chihara, C. marina (Subrahmanyan) Hara et Chihara, and $C$. antiqua (Hada) Ono. The initial density of each prey species offered is shown in Table 1. Dense cultures of three PLD species, C. brodyi, P. shumwayae and $L$. masanensis, were grown on Rhodomonas sp. These species were starved for 3 days and then transferred to a $1 \mathrm{~L}$ polycarbonate (PC) bottle with autoclaved filtered seawater. A microscope was used to determine the density of each predator. One milliliter of the prey culture was also transferred into each of several $50 \mathrm{~mL}$ PC bottles. Duplicate $50 \mathrm{~mL}$ PC bottles (mixtures of each predator and target prey) and control bottles (without prey) were set up for each target prey species. The bottles were capped and then incubated at $20^{\circ} \mathrm{C}$ under $40 \mu \mathrm{mol} \mathrm{m} \mathrm{m}^{-2} \mathrm{~s}^{-1}$ provided with a 12L : 12D cycle using cool white fluorescent lamps. To determine whether each predator was able to feed on each target prey species, the yields of PLD species in the treatment and the control after 4 days of incubation were compared. The growth rate $(\mu)$ of PLD species was calculated using the following equation: $\mu=\ln \left(N_{t} / N_{0}\right) / t$, where $N_{0}$ and $N_{t}$ represent the initial and final cell density of the PLD species at the end of the incubation time $t$ (day), respectively. The growth rates of the PLD species were catego- rized into three levels, i.e., active $\left(>0.25 \mathrm{~d}^{-1}\right)$, positive $\left(<0.24\right.$, or $\left.>0.01 \mathrm{~d}^{-1}\right)$, and negative effects (no growth). In the case of the level being active or positive, feeding behavior of the PLD species on the prey species was observed with a microscope.

The growth response of $C$. brodyi, $P$. shumwayae, and $L$. masanensis as a function of the prey density was examined using Rhodomonas sp. Six or seven titres of initial prey density were prepared $(1.50,2.25,6.00,12.5,20.0,32.5 \times$ $10^{3}$ cells $\left.\mathrm{mL}^{-1}\right)$ at a different initial density for each predator species ( $C$. brodyi, $8.00 \times 10^{2}$ cells $\mathrm{mL}^{-1}$; P. shumwayae, $8.00 \times 10^{2}$ cells $\mathrm{mL}^{-1} ;$ L. masanensis, $2.50 \times 10^{2}$ cells $\mathrm{mL}^{-1}$ ) because we could not achieve the same density. For $C$. brodyi, treatment with $32.5 \times 10^{3}$ cells $\mathrm{mL}^{-1}$ of prey density was omitted. The culture experiments were conducted using $50 \mathrm{~mL}$ PC bottles and freshly filtered seawater. All treatments were conducted in triplicate runs, and the bottles were incubated for 10 days under $20^{\circ} \mathrm{C}$, a salinity of 12 , and illumination conditions of $60 \mu \mathrm{mol} \mathrm{m} \mathrm{m}^{-2} \mathrm{~s}^{-1}$ provided with a $12 \mathrm{~L}: 12 \mathrm{D}$ cycle. The control (without prey) treatments were carried out independently; hence, the initial predator density was slightly different from that in the experiment. Growth rates calculated from daily changes in predator densities were plotted against the prey cell densities, and the results were fitted to the Michaelis-Menten equation as in Montagnes \& Lessard (1999) with Kaleida Graph v.3.6 (Synergy Software): $\mu=\mu_{\max }\left(\mathrm{x}-\mathrm{x}^{\prime}\right) /\left(\mathrm{K}_{\mathrm{GR}}+\right.$ $\left(\mathrm{x}-\mathrm{x}^{\prime}\right)$ ), where $\mu_{\max }=$ the maximum growth rate $\left(\right.$ day $\left.^{-1}\right)$; $\mathrm{x}=$ prey density (cells $\left.\mathrm{mL}^{-1}\right) ; \mathrm{x}^{\prime}=$ the threshold prey density (cells $\mathrm{mL}^{-1}$ ); and $\mathrm{K}_{\mathrm{GR}}=$ half saturation constant.

The effect of temperature on growth was also examined. For the experiments, 6 temperature settings $(5,10,15,20$, 25 , and $30^{\circ} \mathrm{C}$ ) for each predator under a fixed salinity of 12 and illumination conditions of $60 \mu \mathrm{mol} \mathrm{m} \mathrm{m}^{-2} \mathrm{~s}^{-1}$ provided with a $12 \mathrm{~L}: 12 \mathrm{D}$ cycle were established. The evaluation was carried out at the two initial prey (Rhodomonas sp.) densities of $1.50 \times 10^{3}$ and $2.00 \times 10^{4}$ cells $\mathrm{mL}^{-1}$. The experiments were conducted in triplicate by incubating $50 \mathrm{~mL}$ PC bottles over a 4 day period. Two-way ANOVA was carried out to determine the effects of temperature and prey density on the growth rate.

We also examined the growth rate under a wide range of salinity regimes $(0,5,10,15,20,25$, and 30$)$ at 20 and $25^{\circ} \mathrm{C}$ under illumination conditions of $60 \mu \mathrm{mol} \mathrm{m} \mathrm{m}^{-2} \mathrm{~s}^{-1}$ provided with a $12 \mathrm{~L}: 12 \mathrm{D}$ cycle (light condition). In the experiment, continuous dark conditions were also tested to evaluate the effect of light on growth. These experiments were carried out at a prey (Rhodomonas sp.) density of $7.50 \times 10^{3}$ cells $\mathrm{mL}^{-1}$, which was almost at a saturated density for the predator, as described below. These experiments were also conducted in triplicate by incubating $50 \mathrm{~mL}$ PC bottles over 4 days. Two-way ANOVA was carried out to determine the effect of salinity and light on the growth rate.

In the present study, we did not prepare acclimated cultures for each temperature or salinity condition. Hajdu et al. (2000) demonstrated that cultures of $P$. minimum adapted to 
Table 1. Availability of algal planktonic species as food for Pfiesteria-like dinoflagellates, Cryptoperidiniopsis brodyi CCMP 1828, Luciella masanensis CCMP 1835 and Pfiesteria shumwayae CCMP 2807 under the optimal culture conditions. Prey cell densities were obtained at the beginning of the experiment.

\begin{tabular}{|c|c|c|c|c|c|}
\hline Prey types & $\begin{array}{c}\text { Cell size } \\
\text { Length } \times \text { width }(\mu \mathrm{m})\end{array}$ & $\begin{array}{l}\text { Prey cell density } \\
\quad\left(\text { cells } \mathrm{mL}^{-1}\right)\end{array}$ & $\begin{array}{c}\text { C. brodyi } \\
\text { CCMP1828 }\end{array}$ & $\begin{array}{l}\text { L. masanensis } \\
\text { CCMP } 1835\end{array}$ & $\begin{array}{l}\text { P. shumwayae } \\
\text { CCMP } 2807\end{array}$ \\
\hline \multicolumn{6}{|l|}{ Cryptophyceae } \\
\hline Rhodomonas sp. & $10-25 \times 6-13$ & 10,000 & ++ & ++ & ++ \\
\hline \multicolumn{6}{|l|}{$\begin{array}{l}\text { Dinophyceae } \\
\text { thecate }\end{array}$} \\
\hline Prorocentrum micans & $35-70 \times 25-50$ & 500 & - & - & - \\
\hline Prorocentrum minimum & $15-23 \times 10-15$ & 1,500 & - & - & - \\
\hline Prorocentrum triestinum & $18-22 \times 6-11$ & 1,000 & - & - & - \\
\hline Prorocentrum donghaiense & $12-16 \times 10-14$ & 1,000 & - & - & - \\
\hline Alexandrium tamarense & $20-45 \times 20-40$ & 500 & - & - & - \\
\hline $\begin{array}{l}\text { Heterocapsa triquetra } \\
\text { naked }\end{array}$ & $21-32 \times 17-29$ & 1,000 & - & - & - \\
\hline Akashiwo sanguinea & $40-80 \times 35-65$ & 500 & ++ & ++ & ++ \\
\hline \multicolumn{6}{|l|}{ Raphidophyceae } \\
\hline Heterosigma akashiwo & $8-25 \times 6-15$ & 5,000 & ++ & ++ & + \\
\hline Chattonella ovata & $50-70 \times 30-45$ & 500 & + & - & - \\
\hline Chattonella marina & $30-50 \times 20-30$ & 500 & + & - & - \\
\hline Chattonella antiqua & $50-130 \times 30-50$ & 500 & + & - & - \\
\hline
\end{tabular}

++ ; active effect, + ; positive effect, - ; negative effect

each salinity treatment showed higher growth than those directly inoculated into each experimental treatment. However, the optimum salinity conditions did not change due to the adaptation in the experiment. Therefore, we believe that our results validly indicate their response to each culture condition. At least, we can compare three PLD species in their growth response to varying temperature and salinity conditions.

\section{Results}

The feeding behavior of the three PLD species on prey Rhodomonas sp. cells was similar to that of Pfiesteria piscicida, P. shumwayae, and Luciella masanensis (Burkholder \& Glasgow 1995, Jeong et al. 2005a, 2007). Several predator cells attacked each target prey item (data not shown). Some predator cells began removing themselves from the vicinity of target prey cells when the size of the prey cell had gradually decreased or the prey did not move. Predator cells use a peduncle to suck out prey protoplasm and organelles. Finally, the prey was consumed to the last remaining cell.

Among the prey offered in this study, Cryptoperidiniopsis brodyi, L. masanensis, and P. shumwayae were able to feed on the cryptophyte Rhodomonas sp., the raphidophyte Heterosigma akashiwo, and the dinoflagellate Akashiwo sanguinea (Table 1). However, they did not feed on the thecate dinoflagellates Prorocentrum micans, $P$. minimum, $P$. triestinum, . donghaiense, Alexandrium tamarense, or Heterocapsa triquetra. C. brodyi displayed positive growth when it was co-cultured with unarmored raphidophyte species, such as Chattonella ovata, C. marina and C. antiqua (Table 1). In the experiment, we checked that the prey had not been depleted during the 4 days of incubation; hence, the negative growth of the PLD species was not due to the shortage in prey abundance.

Growth rates of the three PLD species rapidly increased with increasing prey cell densities until ca $5.00 \times 10^{3}$ cells $\mathrm{mL}^{-1}$ (Fig. 1). The increase in growth rate gradually decreased at higher prey densities for all three species. Maximum growth rates were 0.49 day $^{-1}$ for $C$. brodyi, 0.64 day $^{-1}$ for L. masanensis, and $0.52 \mathrm{day}^{-1}$ for $P$. shumwayae. Threshold cell densities (growth rate becomes 0) were 270 cells $\mathrm{mL}^{-1}$ for $C$. brodyi, $4.76 \times 10^{2}$ cells $\mathrm{mL}^{-1}$ for $L$. masanensis, and $3.54 \times 10^{2}$ cells $\mathrm{mL}^{-1}$ for $P$. shumwayae.

The growth rates of $C$. brodyi increased with increases in temperature within the range of 15 to $30^{\circ} \mathrm{C}$ (Fig. 2). The highest growth rate of $C$. brodyi was $0.61 \mathrm{~d}^{-1}$ under $2.00 \times$ $10^{4}$ cells $\mathrm{mL}^{-1}$ conditions at $25^{\circ} \mathrm{C}$. The responses in the growth rates of L. masanensis and $P$. shumwayae as functions of temperature and prey densities were similar to those of $C$. brodyi (Fig. 2). Above $15^{\circ} \mathrm{C}$, all three PLD species grew well. At $5^{\circ} \mathrm{C}$ all three PLD species did not grow. At $10^{\circ} \mathrm{C}$, mean growth rates were positive for all three PLD species when prey densities were $2.00 \times 10^{4}$ cells $\mathrm{mL}^{-1}$, whereas they did not grow under prey limited conditions $\left(1.50 \times 10^{3}\right.$ prey cells $\left.\mathrm{mL}^{-1}\right)$. Two-way ANOVA showed there were significant differences in growth rate between temperature conditions (Table 2). Prey density also affected the growth rates. For C. brodyi and P. shumwayae, interaction between temperature and prey density was detected. 

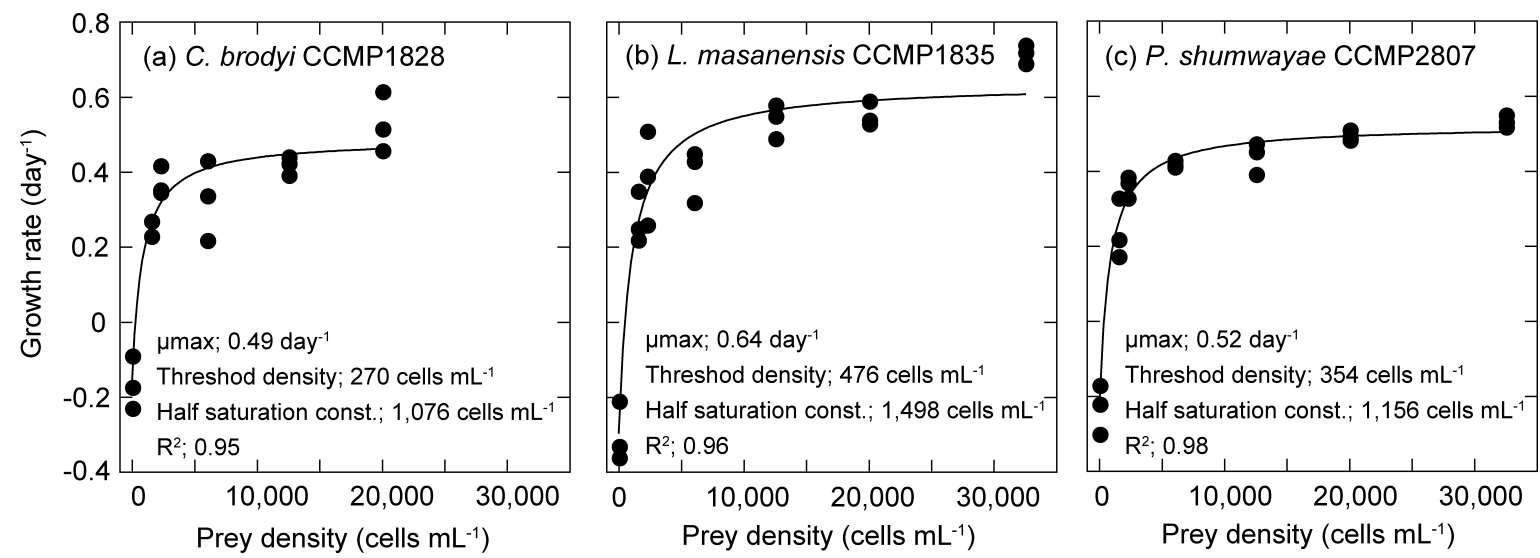

Fig. 1. Growth rates of Pfiesteria-like dinoflagellates as a function of prey density. Rhodomonas sp. was used as a prey. Curves were fitted with a Michaelis-Menten equation. (a); Cryptoperidiniopsis brodyi CCMP 1828, (b); Luciella masanensis CCMP 1835, and (c); Pfiesteria shumwayae CCMP 2807.
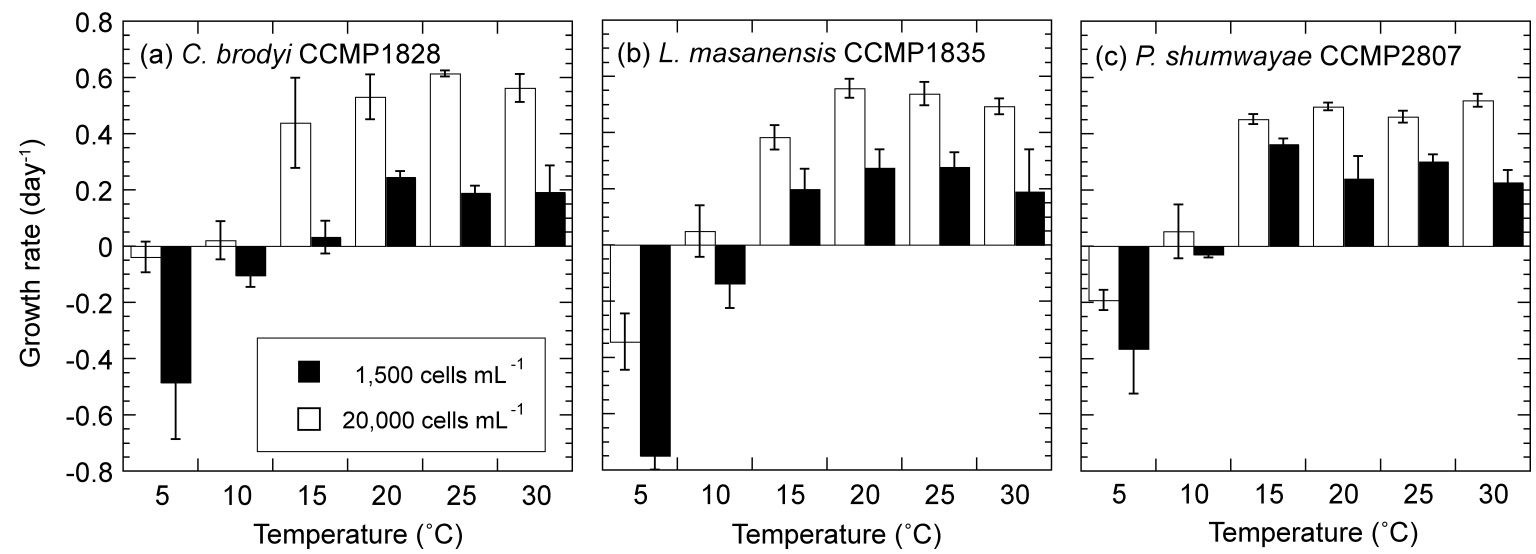

Fig. 2. Effect of temperature on the growth rates of Pfiesteria-like dinoflagellates (PLD). Two prey cell densities were tested for each PLD. Error bars indicate \pm S.D. (a); Cryptoperidiniopsis brodyi CCMP 1828, (b); Luciella masanensis CCMP 1835, and (c); Pfiesteria shumwayae CCMP 2807.

Table 2. Results of two-way ANOVA on the effect of prey density and temperature on the growth rate of Pfiesteria-like dinoflagellates, Cryptoperidiniopsis brodyi CCMP 1828, Luciella masanensis CCMP 1835, and Pfiesteria shumwayae CCMP 2807. Data shown in Fig. 2.

\begin{tabular}{|c|c|c|c|c|c|c|c|c|c|}
\hline \multirow[b]{2}{*}{ Factors } & \multicolumn{3}{|c|}{$\begin{array}{c}\text { C. brodyi } \\
\text { CCMP1828 }\end{array}$} & \multicolumn{3}{|c|}{$\begin{array}{l}\text { L. masanensis } \\
\text { CCMP1835 }\end{array}$} & \multicolumn{3}{|c|}{$\begin{array}{l}\text { P. shumwayae } \\
\text { CCMP2807 }\end{array}$} \\
\hline & DF & F & $p$ & DF & $\mathrm{F}$ & $p$ & DF & $\mathrm{F}$ & $p$ \\
\hline Prey density & 1 & 129.40 & $<0.001$ & 1 & 114.12 & $<0.001$ & 1 & 70.28 & $<0.001$ \\
\hline Temperature & 5 & 55.59 & $<0.001$ & 5 & 148.88 & $<0.001$ & 5 & 121.09 & $<0.001$ \\
\hline Prey X temp & 5 & 2.70 & $<0.05$ & 5 & 1.76 & $>0.05$ & 5 & 2.79 & $<0.05$ \\
\hline Error & 24 & & & 24 & & & 24 & & \\
\hline Total & 35 & & & 35 & & & 35 & & \\
\hline
\end{tabular}

At a salinity range of 5 to 15 , high growth rates of the three PLD species occurred at both 20 and $25^{\circ} \mathrm{C}$ (Fig. 3). The three species did not adapt to zero-salinity conditions with the exception that $P$. shumwayae showed positive growth at 20 and $25^{\circ} \mathrm{C}$. Growth rates of the three PLD species were higher under light than in dark conditions (Fig. 3). Two-way ANOVA showed that differences in growth rate between light- and dark conditions were significant for all three species (Table 3). Salinity also affected their growth rate significantly (Table 3). However, the growth responses to salinity seemed to vary among the species; the population development of $C$. brodyi was achieved within a wide salinity range (10-25, Fig. 3), whereas L. masanensis showed such growth only in a nar- 

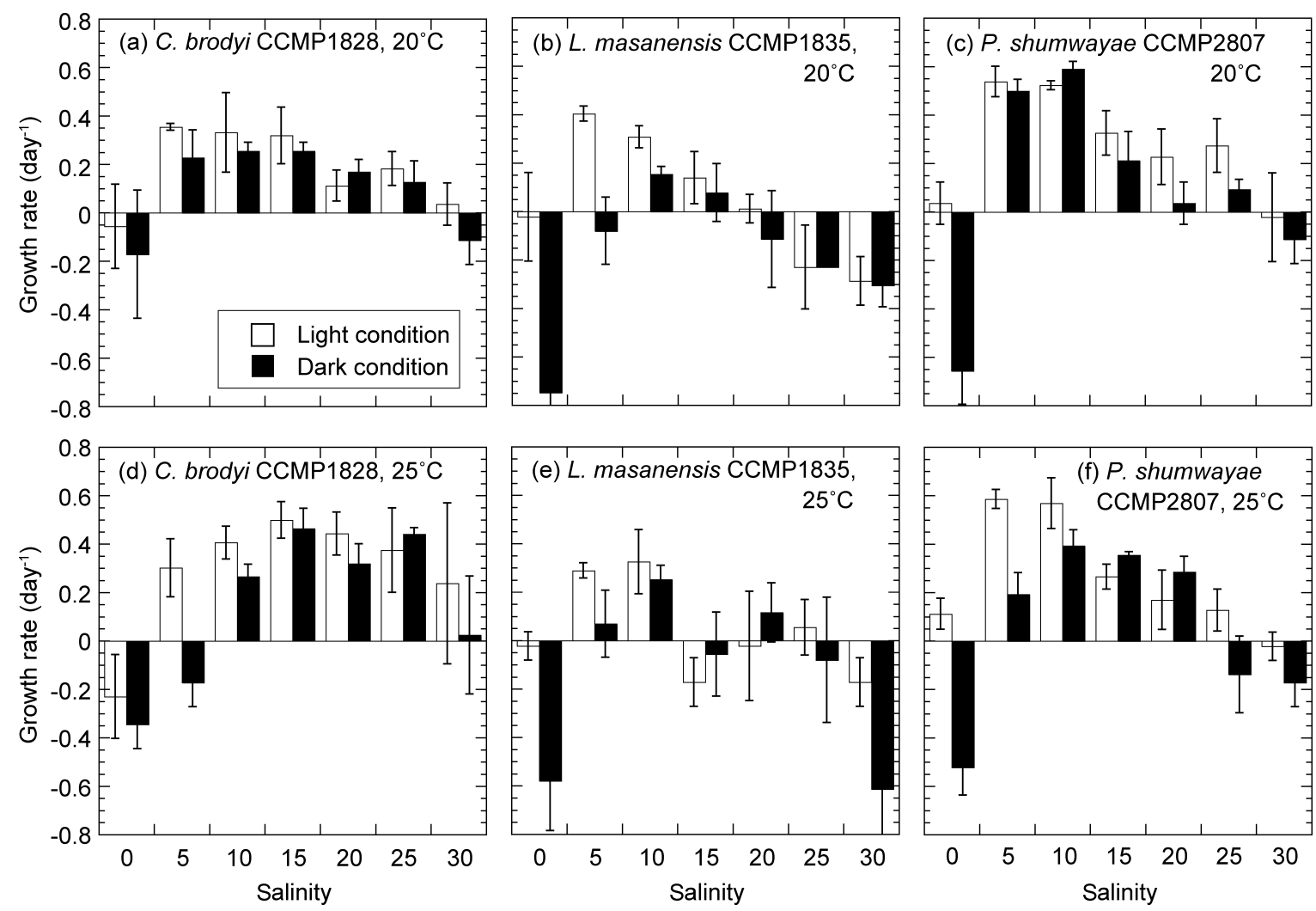

Fig. 3. Effect of salinity on the growth rates of Pfiesteria-like dinoflagellates (PLD). Tests were carried out at two temperature conditions. Without light condition (Dark condition) was also tested. Error bars indicate \pm S.D. (a) and (d); Cryptoperidiniopsis brodyi CCMP 1828, (b) and (e); Luciella masanensis CCMP 1835, and (c) and (f); Pfiesteria shumwayae CCMP 2807.

Table 3. Results of two-way ANOVA on the effect of light and salinity on the growth rate of Pfiesteria-like dinoflagellates, Cryptoperidiniopsis brodyi CCMP 1828, Luciella masanensis CCMP 1835 and Pfiesteria shumwayae CCMP 2807. Data shown in Fig. 3.

\begin{tabular}{|c|c|c|c|c|c|c|c|c|c|c|}
\hline \multicolumn{2}{|c|}{ Temperature } & \multicolumn{2}{|c|}{$\begin{array}{c}\text { C. brodyi } \\
\text { CCMP1828 }\end{array}$} & & \multicolumn{2}{|c|}{$\begin{array}{l}\text { L. masanensis } \\
\text { CCMP1835 }\end{array}$} & \multicolumn{4}{|c|}{$\begin{array}{l}\text { P. shumwayae } \\
\text { CCMP2807 }\end{array}$} \\
\hline 20 & Factors & DF & $F$ & $p$ & DF & $F$ & $p$ & DF & $F$ & $p$ \\
\hline & Light & 1 & 4.34 & $<0.05$ & 1 & 40.09 & $<0.001$ & 1 & 34.15 & $<0.001$ \\
\hline & Salinity & 6 & 11.91 & $<0.001$ & 6 & 26.81 & $<0.001$ & 6 & 58.84 & $<0.001$ \\
\hline & Light $\mathrm{X}$ salinity & 6 & 0.51 & $>0.05$ & 6 & 8.60 & $<0.001$ & 6 & 9.17 & $<0.001$ \\
\hline & Error & 28 & & & 28 & & & 28 & & \\
\hline & Total & 41 & & & 41 & & & 41 & & \\
\hline \multirow[t]{6}{*}{25} & Factors & DF & $F$ & $p$ & DF & $F$ & $p$ & DF & $F$ & $p$ \\
\hline & Light & 1 & 10.67 & $<0.01$ & 1 & 12.73 & $<0.01$ & 1 & 54.25 & $<0.001$ \\
\hline & Salinity & 6 & 20.18 & $<0.001$ & 6 & 15.66 & $<0.001$ & 6 & 52.02 & $<0.001$ \\
\hline & Light $\mathrm{X}$ salinity & 6 & 1.99 & $>0.05$ & 6 & 4.47 & $<0.01$ & 6 & 13.20 & $<0.001$ \\
\hline & Error & 28 & & & 28 & & & 28 & & \\
\hline & Total & 41 & & & 41 & & & 41 & & \\
\hline
\end{tabular}

row salinity range $\left(10-15\right.$ for $20^{\circ} \mathrm{C}, 15-10$ for $25^{\circ} \mathrm{C}$, Fig. $3)$. Among the three species, $P$. shumwayae rapidly increased within the salinity range of 5 to 10 , and the highest rate was $0.59 \mathrm{~d}^{-1}$, observed at a combination of salinity 5 and temperature $25^{\circ} \mathrm{C}$.

\section{Discussion}

Pfiesteria piscicida and Pfiesteria-like dinoflagellates (PLDs) are capable of ingesting various types of organisms (Burkholder \& Glasgow 1995, Seaborn et al. 1999, Burkholder \& Glasgow 2001, Feinstein et al. 2002, Lin et al. 
2004, Jeong et al. 2006,). Due to this feeding ability, these PLD species probably play an important role in the planktonic food webs of estuarine and coastal ecosystems. In particular, the predator-prey relationship between PLD species and red-tide causing species is of interest. However, the prey selectivity of Cryptoperidiniopsis brodyi and $P$. shumwayae had not yet been investigated. The present study provides new information on the prey preferences of C. brodyi, Luciella masanensis, and P. shumwayae.

PLDs use a peduncle for capturing prey organisms, as reported above. Thus, the size of a prey cell does not determine its availability as food. In contrast, the surface structure might be important. Our results showed that thecate dinoflagellates are not available as for prey PLD species (Table 1). A similar result was also reported by Jeong et al. (2006); P. piscicida is able to feed on unarmored phytoflagellates, including Heterosigma akashiwo, whereas they did not feed on thecate mixotrophic dinoflagellates, with the exception of Heterocapsa rotundata (Lohmann) Hansen. In Jeong et al. (2006), P. piscicida efficiently utilized the thecate dinoflagellate $H$. rotundata. However, it is well known that the theca of $H$. rotundata is thin. It is likely that the peduncle of PLDs in the present study was unable to pierce thick theca. Thus, the presence of theca, rather than the size of the organisms, may be a more important feature determing availability as food.

Nevertheless, L. masanensis and P. shumwayae were unable to utilize naked raphidophytes of Chattonella species as prey in the present study (Table 1). Moreover, it has been demonstrated that $P$. piscicida and L. masanensis can utilize diatoms (Jeong et al. 2006, 2007). Jeong et al. (2007) also reported that Stoekeria algicida could not utilize algal plankton other than $H$. akashiwo. These results show that presence, absence or thickness of theca is not the only factor determing food selectivity. Jeong et al. (2007) speculated that the enzymes for prey recognition and/or digestion may differ between PLDs. Therefore, factor(s) other than cell size and the presence of theca affecting the availability of planktonic organisms as food for PLDs should be investigated further. Although food selectivity has not yet been clarified, it is obvious that prey preferences differ between PLDs, and this probably enables their coexistence in the same body of water.

Growth rates of the three PLD species were saturated at $>5.00 \times 10^{3}$ cells $\mathrm{mL}^{-1}$ (Fig. 1). This is similar to the results for P. piscicida (Jeong et al. 2006). The growth rate of the dinoflagellate, Gymnodinium sp. was saturated at $<2.00 \times 10^{3}$ cells $\mathrm{mL}^{-1}$ when Rhodomonas salina (Wislouch) Hill et Wetherbee was used as prey (Jakobsen \& Hansen 1997). Jeong et al. (2005b) reported the feeding of red tide-causing dinoflagellates on an unidentified cryptophyte strain. The growth rates of these dinoflagellates were saturated above $3.00 \times 10^{3}$ cells of cryptophyte per milliliter (Jeong et al. 2005b). These results show that our results are within a similar range to those of previous studies.

The present study shows that the highest growth rates of
C. brodyi, L. masanensis, and P. shumwayae were $0.61 \mathrm{~d}^{-1}$ at $25^{\circ} \mathrm{C}, 0.54 \mathrm{~d}^{-1}$ at $20^{\circ} \mathrm{C}$, and $0.72 \mathrm{~d}^{-1}$ at $20^{\circ} \mathrm{C}$, respectively (Fig. 2). Below $10^{\circ} \mathrm{C}$, growth rates of the three PLD species were close to zero under prey saturated conditions $\left(2.00 \times 10^{4}\right.$ cells $\left.\mathrm{mL}^{-1}\right)$, and were negative under prey limited conditions $\left(1.50 \times 10^{3}\right.$ cells $\mathrm{mL}^{-1}$, Fig. 2). Glasgow et al. (1998) demonstrated that P. piscicida has a maximum growth rate of $1.1 \mathrm{~d}^{-1}$ at high temperatures (around $25^{\circ} \mathrm{C}$ ). Rublee et al. (2006) reported that environmental conditions during P. piscicida and P. shumwayae blooms were characterized by low turbulence, warm temperatures, and high nutrient and chlorophyll $a$ concentrations. Similar to $P$. piscicida, the present three PLD species also prefer higher temperatures $\left(15-30^{\circ} \mathrm{C}\right)$.

At $10^{\circ} \mathrm{C}$, the mean growth rates for the three PLD species were negative when experiments were started at $1.50 \times 10^{3}$ prey cells $\mathrm{mL}^{-1}$ (Fig. 2). On the other hand, when experiments were carried out at higher initial prey densities, growth rates became positive, although the differences in growth rates between $1.50 \times 10^{3}$ and $2.00 \times 10^{4}$ cells $\mathrm{mL}^{-1}$ were not obvious (Fig. 2). In addition, in the case of $C$. brodyi and $L$. masanensis, the growth rates were higher in the $2.00 \times 10^{4}$ cells $\mathrm{mL}^{-1}$ treatment at $15^{\circ} \mathrm{C}$ (Fig. 2). These results indicate the interactive effect of temperature and prey density on their growth rates. Prey abundance is probably critical for their survival under severe conditions.

Blooming of P. piscicida and PLDs mostly occurs in estuaries, implying that the organisms have to achieve broad salinity tolerance to survive under such harsh environmental conditions. As Sullivan \& Andersen (2001) demonstrated, a total of 62 PLD strains are able to grow over a wide range of salinity ( 0 to 35 ), and several strains swum at salinities exceeding 35-45. In the present study, growth responses of the three PLD species against salinity differed (Fig. 3) from those shown in Sullivan and Andersen (2001). The three species tested in the present study showed different salinity tolerances, although higher growth rates were observed at a salinity of 5 to 15 in all species (Fig. 3). These results indicate that acceptable salinity ranges differ among PLD species; however, optimal salinity ranges are similar.

The present study demonstrated that light has a positive effect on the growth rates of C. brodyi, L. masanensis, and P. shumwayae (Fig. 3, Table 3). There are two possible explanations for this result. One is the nutrition of prey organisms. All prey organisms tested in the present study were phototrophic. Thus, the nutritive condition of prey organisms possibly affected the growth of PLDs, especially in the latter part of the experimental period (4 days), although we do not have any data supporting this hypothesis. The other is mixotrophy of PLDs. Eriksen et al. (2002) demonstrated the mixotrophy of Cryptoperidiniopsis sp. by kleptoplastidy. Unfortunately, the present study does not show any additional evidence to support their mixotrophy, however, it is possible that these three PLD species possess mixotrophy. This should be examined in the future. 
In conclusion, the present study demonstrated that PLD species are eurythermal and prefer low salinity (5-15). PLD species can utilize HAB species other than thecate dinoflagellates. Recently, Pfiesteria and PLD species have been detected in coastal waters worldwide, even in low abundances. Therefore, blooms of PLDs possibly occur after blooms of naked phytoplankters outside of the winter season in temperate estuaries. These small dinoflagellates should be carefully monitored in such situations.

\section{Acknowledgements}

We are grateful to Prof. M.S. Han for his support of the experiments, including the purchase of strains. Thanks are also due to Prof. K. Yoshino, Dr. M. Yoshida for valuable discussions. This research was supported by a Korea Research Foundation grant (KRF-2007-355-00060), a grant from KORDI's project (PE98464) and a Grant-in-aid for Scientific Research (C) (20589002).

\section{References}

Burkholder JM, Glasgow HB (1995) Interaction of a toxic estuarine dinoflagellate with microbial predators and prey. Arch Protistenkd 145: 177-188.

Burkholder JM, Glasgow HB (1997) Pfiesteria piscicida and other Pfiesteria-like dinoflagellates: behavior, impacts, and environmental controls. Limnol Oceanogr 42: 1052-1075.

Burkholder JM, Glasgow HB (2001) History of toxic Pfiesteria in North Carolina estuaries from 1991 to the present. BioScience 51: 827-841.

Burkholder JM, Noga EJ, Hobbs CW, Glasgow HB, Jr. Smith SA (1992) New 'phantom' dinoflagellate is the causative agent of major estuarine fish kills. Nature 358: 407-410.

Eriksen NT, Hayes KC, Lewitus AJ (2002) Growth responses of the mixotrophic dinoflagellates, Cryptoperidiniopsis sp. and Pfiesteria piscicida, to light under prey-saturated conditions. Harmful Algae 1: 191-203.

Feinstein TN, Traslavina R, Sun M, Lin S (2002) Effects of light on photosysthesis, grazing and population dynamics of the heterotrophic dinoflagellate Pfiesteria piscicida (Dinophyceae). J Phycol 38: 659-669.

Glasgow HB, Burkholder JM, Mallin MA, Deamer- Melia NJ, Reed RE (2001) Field ecology of toxic Pfiesteria complex species and a conservative analysis of their role in estuarine fish kills. Environ Health Perspect 109: 715-730.

Glasgow HB, Lewitus AJ, Burkholder JM (1998) Feeding behavior of the ichthyotoxic estuarine dinoflagellate, Pfiesteria piscicida, on amino acids, algal prey, and fish vs. mammalian erythrocytes. In: Harmful microalgae. Intergovernmental Oceanographic Commission of UNESCO (eds Reguera B, Blanco J, Fernandez ML, Wyatt T). Paris, pp. 394-387.

Gordon A, Dyer B, Seaborn D, Marshall H (2002) Comparative toxicity of Pfiesteria spp., prolonging toxicity of $P$. piscicida in culture and evaluation of toxins stability. Harmful Algae 1: 8594.

Hajdu S, Edler L, Olenina I, Witek B (2000) Spreading and estab- lishment of the potentially toxic dinoflagellates Prorocentrum minimum in the Baltic Sea. Int Rev Gesamten Hydrobiol 85: 561-575.

Jakobsen HH, Hansen PJ (1997) Prey size selection, grazing and growth response of the small heterotrophic dinoflagellate Gymnodinium sp. and the ciliate Balanion comatum--a comparative study. Mar Ecol Prog Ser 158: 75-86

Jeong HJ, Ha JH, Park JY, Kim JH, Kang SK, Kim S-H, Kim JS, Yoo YD, Yih WH (2006) Distribution of the heterotrophic dinoflagellate Pfiesteria piscicida in Korean waters and its consumption of mixotrophic dinofalgellates, raphidophytes and fish blood cells. Aquat Microb Ecol 44: 263-278.

Jeong HJ, Ha JH, Yoo YD, Park JY, Kim JH, Kang NS, Kim TH, Kim HS, Yih WH (2007) Feeding by the Pfiesteria-like heterotrophic dinoflagellate Luciella masanensis. J Eukaryot Microbiol 54: 231-241.

Jeong HJ, Kim JS, Park JY, Kim JH, Kim S, Lee I, Lee SH, Ha JH, Yih WH (2005a) Stoeckeria algicida n. gen., n. sp. (Dinophyceae) from the coastal waters off southern Korea: morphology and small subunit ribosomal DNA gene sequence. J Eukaryot Microbiol 52:382-390.

Jeong HJ, Yoo YD, Park JY, Song JY, Kim ST, Lee SH, Kim KY, Yih WH (2005b) Feeding by phototrophic red-tide dinoflagellates: five species newly revealed and six species previously known to be mixotrophic. Aquat Microb Ecol 40:133-150

Lin S, Mulholland MR, Zhang H, Feinstein TN, Jochem FJ, Carpenter EJ (2004) Intense grazing and prey-dependent growth of Pfiesteria piscicida (Dinophyceae). J Phycol 40: 1062-1073.

Litaker W, Tester P, Colorni A, Levy M, Noga E (1999) The phylogenetic relationship of Pfiesteria piscicida, cryptoperidiniopsoid sp., Amyloodinium ocellatum, and a Pfiesteria-like dinoflagellate to other dinoflagellates and amphicomplexans. J Phycol 35: $1379-1389$.

Mason PL, Litaker RW, Jeong HJ, Ha JH, Reece KS, Stokes NA, Park JY, Steidinger KA, Vandersea MW, Kibler S, Tester PA, Vogelbein WK (2007) Description of a new genus of Pfiesterialike dinoflagellate, Luciella gen. nov. (Dinophyceae), including two new species: Luciella masanensis sp. nov. and Luciella atlantis sp. nov. J Phycol 43: 799-810.

Montagnes DJS, Lessard EJ (1999) Population dynamics of the marine planktonic ciliate Strombidinopsis multiaris: its potential to control phytoplankton blooms. Aquat Microb Ecol 20: 167-181.

Park TG, de Salas MF, Bolch CJS, Hallegraeff GM (2007) Development of a real-time PCR probe for quantification of the heterotrophic dinoflagellate Cryptoperidiniopsis brodyi (Dinophyceae) in environmental samples. Appl Environ Microbiol 73: $2552-2560$.

Parrow MW, Burkholder JM (2003) Estuarine heterotrophic cryptoperidiniopsoids (Dinophyceae): life cycle and culture studies. J Phycol 39: 678-696.

Rublee PA, Nuzzi R, Waters R, Schaefer EF, Burkholder JM (2006) Pfiesteria piscicida and Pfiesteria shumwayae in coastal waters of Long Island, New York, USA. Harmful Algae 5: 374379.

Rublee RA, Remington DL, Schaefer EF, Marshall MM (2005) Detection of the dinozoans Pfiesteria piscicida and $P$. shumwayae: a review of detection methods and geographic dis- 
tribution. J Eukaryot Microbiol 52: 83-89.

Seaborn DW, Seaborn AM, Dunstan WM, Marshall HG (1999) Growth and feeding studies on the algal feeding stage of a $P f i$ esteria-like dinoflagellate. Vir J Sci 50: 337-344.

Seaborn DW, Tengs T, Cerbin S, Kokocinski M, Marshall HG (2006) A group of dinoflagellates, similar to Pfiesteria as defined by morphology and genetic analysis. Harmful Algae 5: 1-8.

Steidinger KA, Landsberg JH, Mason PL, Vogelbein WK, Tester PA, Litaker RW (2006) Cryptoperidiniopsis brodyi gen. et sp. nov. (Dinophyceae), a small lightly armored dinoflagellate in the Pfiesteriaceae. J Phycol 42: 951-961.

Steidinger K, Landsberg J, Richardson RW, Truby E, Blakesley B, Scott P, Tester P, Tengs T, Mason P, Morton S, Seaborn D, Litaker W, Reece K, Oldach D, Haas L, Vasta G (2001) Classifi- cation and identification of Pfiesteria and Pfiesteria-like species. Environ Health Perspect 109: 661-665.

Sullivan BE, Andersen RA (2001) Salinity tolerance of 62 strains of Pfiesteria and Pfiesteria-like heterotrophic flagellates (Dinophyceae). Phycol Res 49: 207-214.

Taylor FJR (1999) Morphology (tabulation) and molecular evidence for dinoflagellate phylogeny reinforce each other. J Phycol 35: 1-6. 